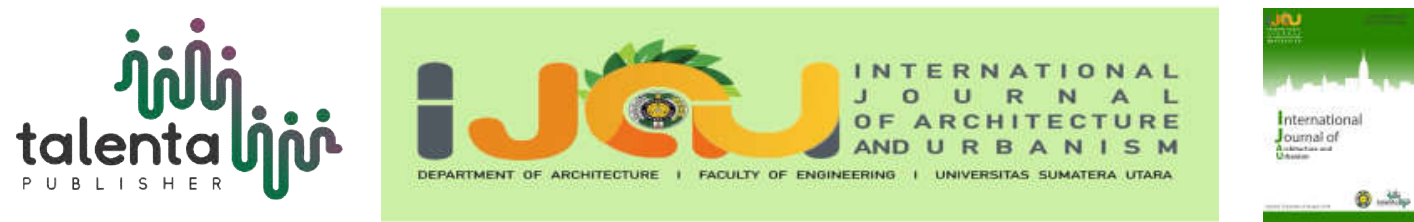

\title{
Planning of Tigaras Dock in Simalungun Regency (With Organic Architecture Design Approach)
}

\author{
Nurlisa Ginting ${ }^{1 *}$, Neny Wiyanti ${ }^{1}$ \\ ${ }^{I}$ Department of Architecture, Universitas Sumatera Utara, Medan, Indonesia
}

\begin{abstract}
Simalungun Regency is an autonomous region that has quite a wealth of natural resources that require maximum development. Tourism development in Simalungun Regency has a very significant and strategic meaning. A tourism sector is a mainstay plane that is expected to support the development of regional development. The tourism is also not free from the available facilities and infrastructure such as port as a means of transport inter-island liaison. The Tigaras Ferry pier is one of the existing ports to connect the Tigaras districts with Simanindo in Samosir District. Tigaras dock at this time not so noticed by the local government, but the area is an alternative port in the field as a liaison to the island of Samosir through Simanindo pier. Supporting infrastructure in the region is also inadequate. The arrangement of Tigaras and the design of dock terminal building and public place using organic theme then produce that connect the aspect of the outer and inner space. Buildings with the formation of a mass of course organic, as well as the public area that can attract visitors to be more environmentally conscious. Through this revitalization, the designer hopes to facilitate passengers or people who will cross to Samosir Island by using this Tigaras dock.
\end{abstract}

Keyword: tourism, facility, organic, water

\section{Introduction}

The Tigaras ferry dock is one of the existing ports to connect the Tigaras districts with Simanindo in Samosir District. This harbor has 2 (two) docks as entrance and exit of human/goods doing crossing activities from the bland and the lakeside. Tigaras dock at this time not so noticed by the local government, but the area is an alternative port in as a liaison to the island of Samosir through Simanindo pier. The construction of facilities and infrastructure in Tigaras districts of Simalungun Regency covers the pedestrian area ecstasy, kiosk or retail development, restaurant, parking of two and four wheelers, tourist boat dock (wood ferry) and ferry boat. Limitations of research the effect of the arrangement of the region on the quality of public space and economic improvement of people in Tigaras dock district of Simalungun Regency is: Arrangement of circulation in the port area, both for pedestrian and motor, make of parking includes parking queue of vehicles, construction of kiosks or retail, sitting, development

\footnotetext{
*Corresponding author at: Department of Architecture, Faculty of Engineering, Universitas Sumatera Utara,

Jalan Perpustakaan Gedung J07, Medan 20155, Indonesia

E-mail address: nurlisa.ginting@gmail.com
} 
of service, the management office, mosques and toilets, gallery, and restaurant, as a waiting room for vessels, with the consideration that these facilities and infrastructure are the most widely used by the public.

\section{Literature Review}

\section{Object Description}

The definition of the Planning of Tigaras Dock in Simalungun Regency is to re-arrange the planned area as a means of transportation or damaged area that supports the crossing, equipped with various other functions as entertainment recreation while enjoying the potential that exists in nature located in Nagori Tigaras Simalungun regency.

\section{Location and Site}

Site location is Tigaras District Dolok Pardamean Simalungun regency. North Sumatra, which is the tourist gate to go to Samosir Island. The distance traveled to the Tigaras Dock is $50.1 \mathrm{~km}$ from Pematang Siantar City and $14.5 \mathrm{~km}$ from Kecamatan Dolok Pardamean. There is only one ramp-filled and derived path. The pier can reach the road by land travel, accessible by private transport or public transport, and also uses water travel from Simanindo wharf by ferry tour and Tao Toba boat. Concerning the graphic illustration related to the location of the project as follows (Figure 1).

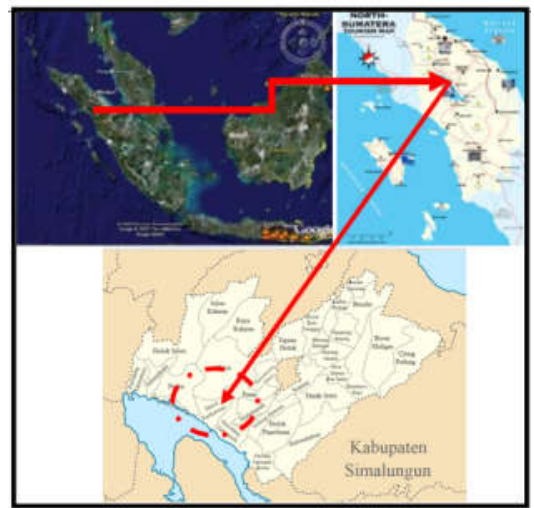

Figure 1. Maps of Location Site (Source:https://www.google.com/earth)

\section{Theme Review}

For a design process, the theme is one of the core factors in the design. The basic design plan becomes the direction in the design process by starting from the concept and analyzing to produce results. Themes can also provide distinctive features for a design with other designs. The selection of Organic Architecture is the desire to create conditions and atmosphere between the physical building and outer space make together in a continuity that can help in relaxing the mind and body of visitors and passengers who come. 
An artificial environment that has a variety of uses to protect human beings and their activities and property from elements, and from supernatural powers to create places, create a secure, populated area in a mortal and quite a dangerous world, emphasize social and accentuating status [2]. Architecture is planned and built in response to specific desires. Which sometimes only based on function or maybe a reflection on certain conditions [1]. It can be judging from some understanding of the architecture; it can be concluded that is a made environment with the aim to protect humans in life to interact with the surrounding natural environment.

The term "organic" was first revealed and described by biologists and anthropologists in the 1800s, namely Bichat, Linnaeus, Buffon, Lamark, Darwin and Van Hombolt. It is the architecture which is base on the development of the principle of development and growth of nature. The horizontal line is the most significant architectural line, feels there is an array bond between nature and architecture. Wright's works follow the basis that the new form of meaning if it has the clarity of principle, which architecture is the link between human and the environment. That is the architecture of nature, which is base on the development of the basic of development [3]. Several aspects that support the project design of organic architecture in buildings (Table 1).

Table 1. Aspects of Organic Architecture Design

\begin{tabular}{|c|c|c|}
\hline $\begin{array}{c}\text { ORGANIC } \\
\text { ARCHITECTURE }\end{array}$ & ASPECT & DESIGNING INSTRUCTIONS \\
\hline \multirow{3}{*}{$\begin{array}{l}\text { Shape building } \\
\text { harmonious with } \\
\text { nature }\end{array}$} & $\begin{array}{l}\text { Buildings are formed } \\
\text { naturally from the site }\end{array}$ & $\begin{array}{l}\text { Eliminate the box's impression of the } \\
\text { building and adjust the area }\end{array}$ \\
\hline & $\begin{array}{l}\text { Buildings are formed in } \\
\text { harmony with the proportion } \\
\text { of the human body }\end{array}$ & $\begin{array}{l}\text { Proportion of buildings and scale using } \\
\text { fair. }\end{array}$ \\
\hline & Building closer to earth. & $\begin{array}{l}\text { Using horizontal elements that seem } \\
\text { parallel to the ground surface of the } \\
\text { construction is not too high. }\end{array}$ \\
\hline $\begin{array}{l}\text { Organization dynamic } \\
\text { space }\end{array}$ & $\begin{array}{l}\text { Space seemed to flow } \\
\text { continuously }\end{array}$ & $\begin{array}{l}\text { Arrangement of radial building masses } \\
\text { (flowing in all directions) circulation of } \\
\text { place in the radial and linear patterns, the } \\
\text { floor plan to adjust the shape of the site. }\end{array}$ \\
\hline \multirow{2}{*}{$\begin{array}{l}\text { Unity of space in outer } \\
\text { space }\end{array}$} & $\begin{array}{l}\text { No impression of inner and } \\
\text { outside area }\end{array}$ & $\begin{array}{l}\text { The existence of the park within the } \\
\text { building removes some of the walls that } \\
\text { separate the outer gate and the inner gate. }\end{array}$ \\
\hline & Exposure & $\begin{array}{l}\text { Increases openings for natural light into } \\
\text { the building. }\end{array}$ \\
\hline \multirow{3}{*}{$\begin{array}{l}\text { Materials, colors, } \\
\text { ornaments related to } \\
\text { nature }\end{array}$} & Material from nature & $\begin{array}{l}\text { Mostly using natural materials such as } \\
\text { wood, bamboo, and rock. }\end{array}$ \\
\hline & $\begin{array}{l}\text { Colors are as natural as } \\
\text { possible }\end{array}$ & $\begin{array}{l}\text { The use of colors close to natural colors } \\
\text { such as green, brown, and other colors }\end{array}$ \\
\hline & $\begin{array}{l}\text { Ornaments are the unity of } \\
\text { material }\end{array}$ & $\begin{array}{l}\text { Ornaments are not just patches. Or } \\
\text { carvings on natural stone. Ornament } \\
\text { patterns are aligned and blended with } \\
\text { nature. For example; Artificial texture on } \\
\text { concrete. }\end{array}$ \\
\hline
\end{tabular}


While organic does represent environmental concerns, it also embodies the human spirit, transcending of the shelter into something which enhances our lives and shapes. While organic architecture does describe an expression of individuality, it also explores our need to connect nature. The building to be built is an application of organic architecture. The especially selection of the theme is the desire to create conditions and atmosphere between the physical building and outer space make together in a continuity that can help in relaxing the mind and body of visitors and passengers who come. This builds itself with the establishment of a continuous situation is expected to have its charm and can give the impression that is not tiring nor of complexity on the development.

\section{Methodology}

In the design of this project, the method used at the time of site selection is a qualitative method with descriptive research. Research methods with conducted to describe the process or events that in the field used as the object, then the data or information in the analysis so that obtained a problem-solving. Comparison of site area with planned facilities and limited the land area regulations, looking for information the land status and consider topology and the environment. Data collection technique this design is library studies is a secondary file in the form of literary studies that have a relationship with the titles and themes discussed in the thesis to strengthen the facts naturally, field observation (survey), conducted by making observation and data collection directly in the location so as to know and feel the atmosphere around right and group discussion share in order to open mind and add ideas in designing and determining the space program created [4].

\section{Result and Discussion}

\section{Site Analysis}

The user/user on the terminal consists of 4 (four) major groups, namely: terminal manager dock is the Third Rd terminal is the Department of Transportation of Simalungun Regency run by Ferry office. Operation Ferry handled by each ferry company in the terminal Tigaras dock, the passenger people who use terminal services to get on or off to the ship and proceed to other modes of transportation. The passengers in the terminal of this dock that is tourists (local community), introduction/general, business owner, and service. Scale and site's limitations: area of Site: $\pm 2 \mathrm{Ha}$, beach border: 30-50 m, width of Jalan Saribu Dolok is five demands a total area of Effective: Total - coastline line is 19,678 m2 - 40=1.9 Ha.

Data tread around Tigaras dock area is the site is directly adjacent to the hill on the north side of the site, site location is on the main road, reside is very potential to be developed, around the tread is more beautiful filled with plants, around the site is still empty and slightly contained, it is directly adjacent to Lake Toba. Design response, overall the existence of the site has 
advantages and disadvantages in the view. Because on the two sides of the north and south of the impression of the field because there are no obstacles in the site, overall view of the area is better.

The view there is a hindered settlement resident with the third floor, namely on the view west. But the best scene is on the side of the site to Lake Toba and hills, and the whole spot is situated to good use, avoiding excessive solar heat, make artificial, or natural shading as well as vegetation the orientation of the building is extending in the direction of East-West. Then the constructions a mass parallel to the coming of the wind, to reduce the noise source around can be done by making a buffer that is by using vegetation, lower air pollution then gave buffering in the form of the tree.

\section{Basic Concept}

The basic plan of Tigaras in Simalungun Regency is to interpret the application of the theme of organic architecture that combines space, environment, and integrity. Taking into consideration the maximum utilization of Lake Toba that is the view obtained from Lake Toba, then the designer will make visitors or passengers more enjoy the beauty. By the theme desired the planner that is lifting the line of organic architecture as an approach to the title is appoint, Lake Toba also as a clear liaison to form a unified whole to the overall design. Starting from job or bend of lake water waves, the designer began to move regarding concept development. Starting from the formation of building a mass composition that curved like a wave that is continuous with the forming of lines that are not massive (Figure 2). Buildings must be open towards nature and blend with the landscape lines is the principle of organic architecture.

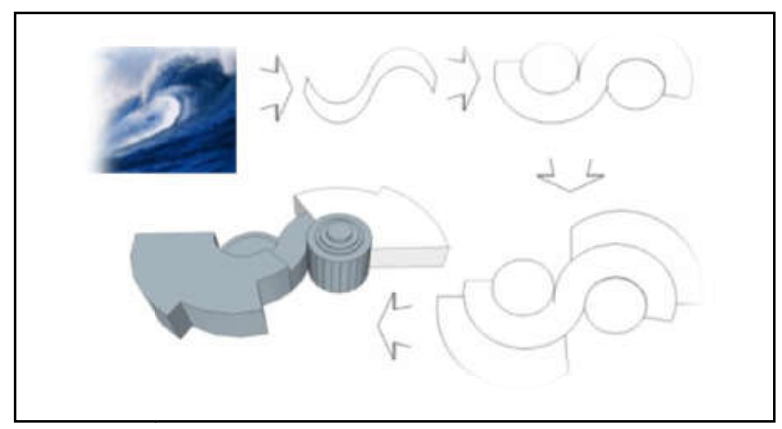

Figure 2. Mass Composition of Building

The designer also creates a contour that leads closer to a lake that has a wavelike shape. Outlining is used as a public area for visitors and passengers who want to enjoy the lake Toba itself. Next is the concept of the designer approach that is organic, by making the form of unity by inserting natural elements into the site by using the particle of lake water into the area. Its function is a rainwater container from the roof of the building. Establishing the space outside the building can be seen with a line that is not boring it creates a good impression on visitors or 
passengers. The designer also makes the building facade of the arch formation according to the mass composition that has been formed, by applying into the wall of the building (Figure 3).

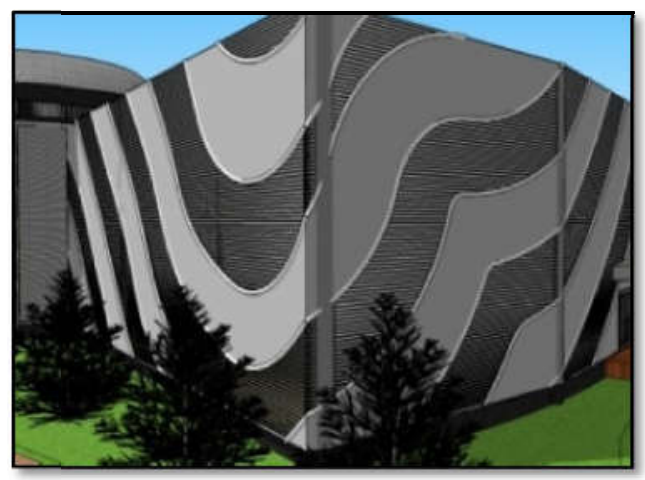

Figure 3. Building Facade of Building

\section{Site Zoning Concept}

The plan of zoning is a form of response from the tread analysis that already completed. That is done to organize the design area into a more orderly and better laying. The different of parking for passengers who will cross the island of Samosir with management, introduction or passenger pickup became one of the concepts of parking arrangement on this Tigaras roar. The parking that leads to the passenger parking and fetches must round the drop off first to avoid the occurrence of cross circulation. The different of the parking consists of the parking area of the queue of the vehicle that will be crossing, passenger car park / pick up a passenger or public car park, motorcycle vehicle park, bus park and vehicle park for dock manager (Figure 4).

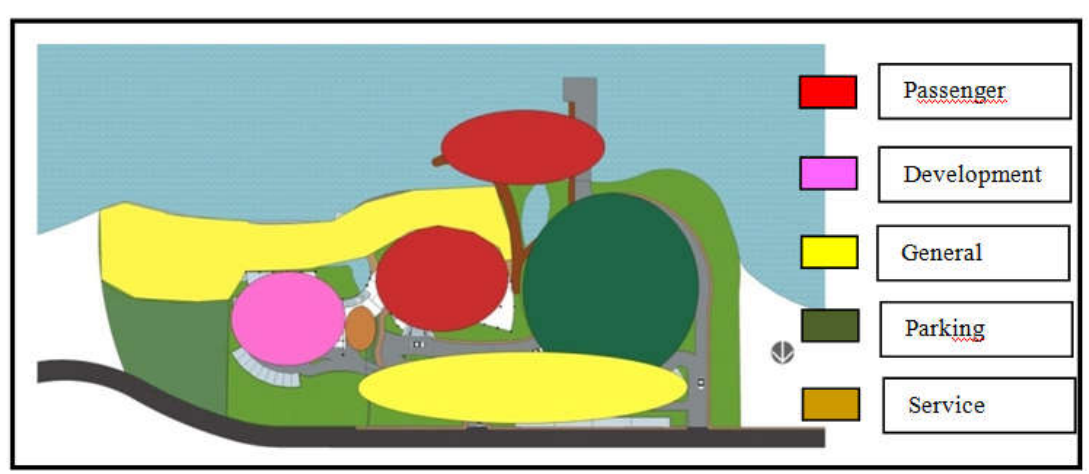

Figure 4. Site Zoning

\section{Concept of Outer and Concept of Inner Space}

That is public parking spaces, outdoor restaurants and also pedestrian paths by using the canopy as a protector from the sun and when it rains.Parking zones were different according to the users of passenger car parking that crossed, parking delivery and pickup, and parking manager (Figure 5). The relationship between running inside the building (Figure 6). 


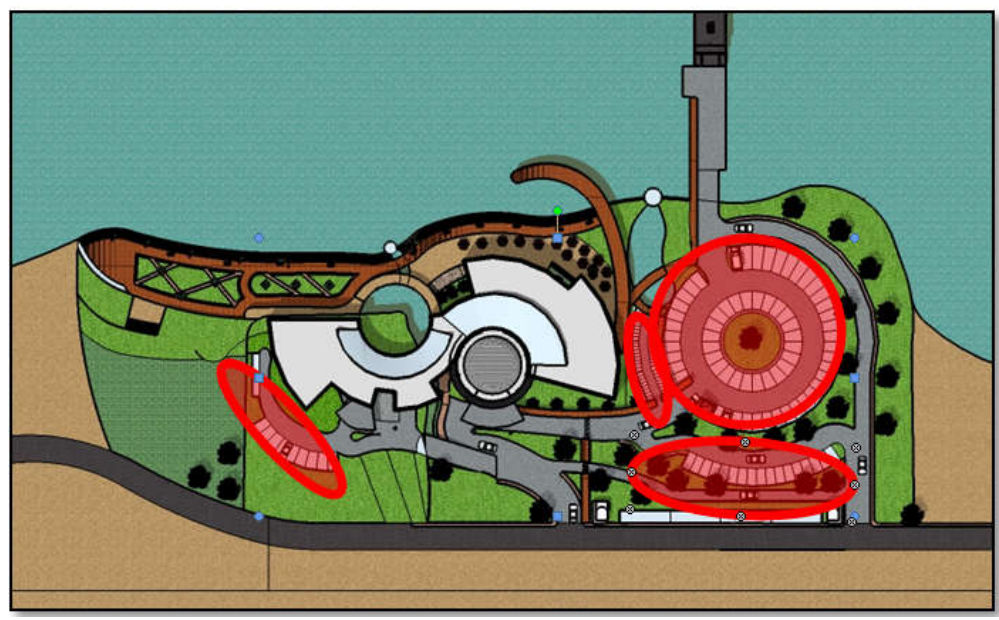

Figure 5. Concept of Outer Space

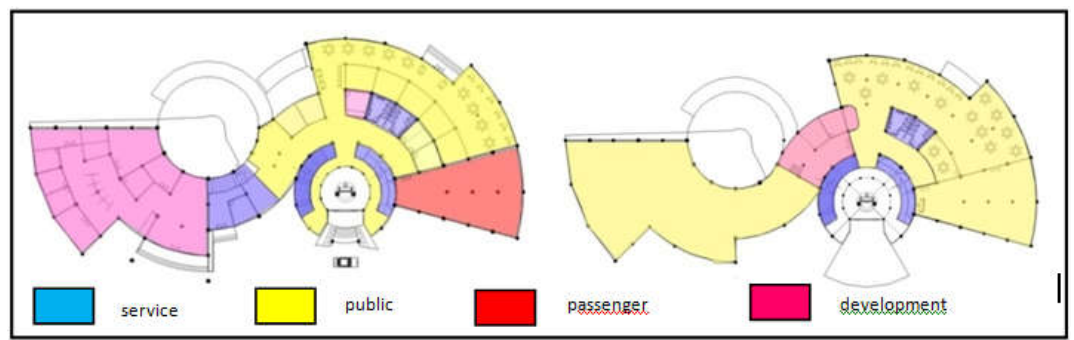

Figure 6. Concept of Inner Space

\section{Architecture Design}

The concept of placing the incoming and outgoing areas for vehicles from the main road-entry to the site or out to the main road, then come out the idea or response from the results of the achievement analysis and zoning site. Can be seen from the concept drawing outline engineering on the area is with any access in and out of the building. By car is directed to pass the one-way drop-off or directly to the car seat ticket to the ship or straight to the parking lot for the introductory and pickup and then leads to access out of the thread. Create one-way access to make a difference in access and exit access that can reduce congestion the site if there is an increase a vehicle that will cross suddenly (Figure 7).

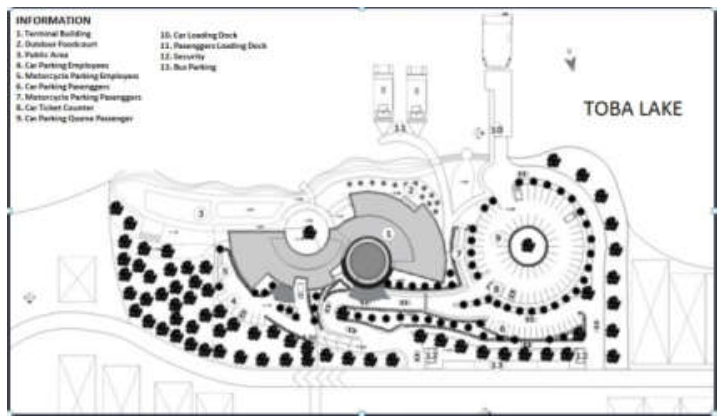

Figure 7. Site Plan 
Visible building view from the front which is an entrance area for drop-off cars and access to entry (Figure 8). The side is showing the outdoor food court area and parking area vehicles (Figure 9).

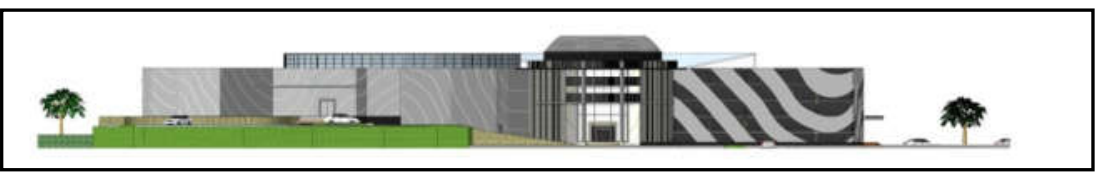

Figure 8. Front View of The Building

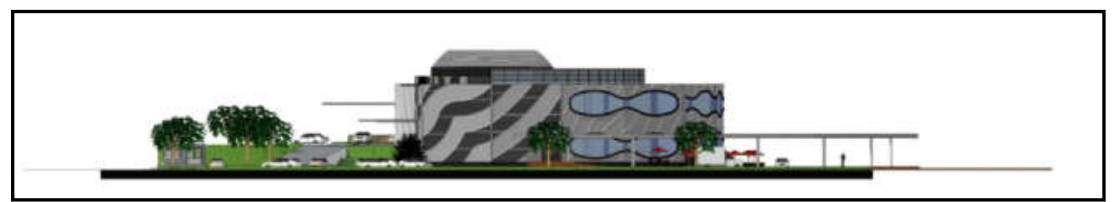

Figure 9. Side View of The Building

Tigaras Dermanga of Simalungun Regency which consists of building perceptions when viewed from ships in Lake Toba (Figure 10), outdoor food court area (Figure 11), perspective when viewing from the management side with bird eye eyes (Figure 12). Interior inside a building like a restaurant area on the 2nd floor (Figure 13), waiting for area passengers (Figure 14), building management area (Figure 15).

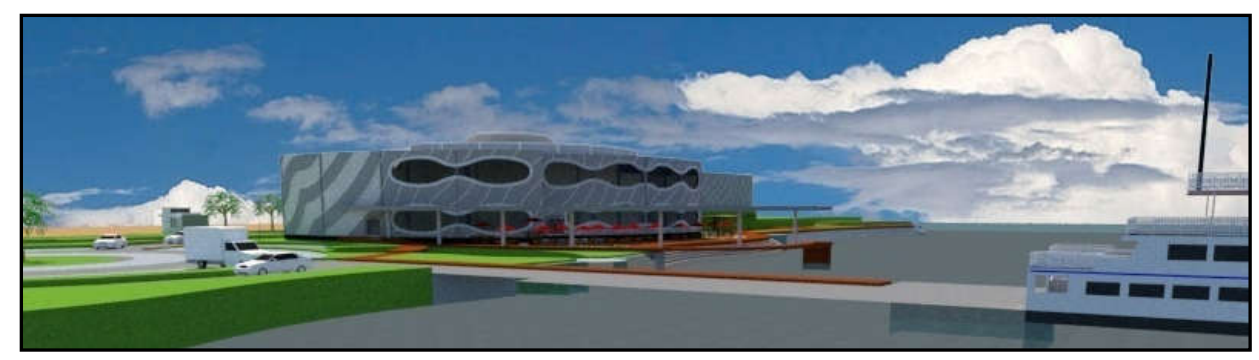

Figure 10. Exterior Architectural Design Result

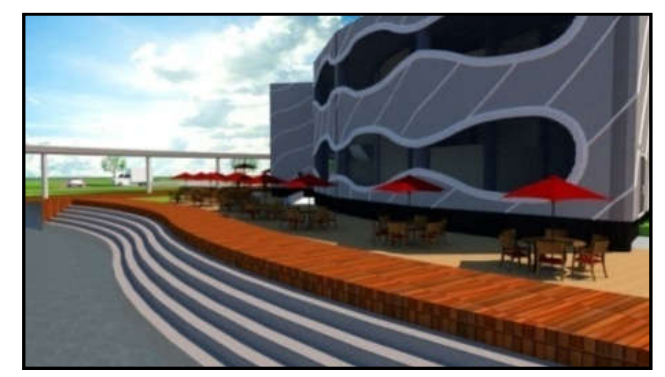

Figure 11. Outdoor Foodcourt Area 


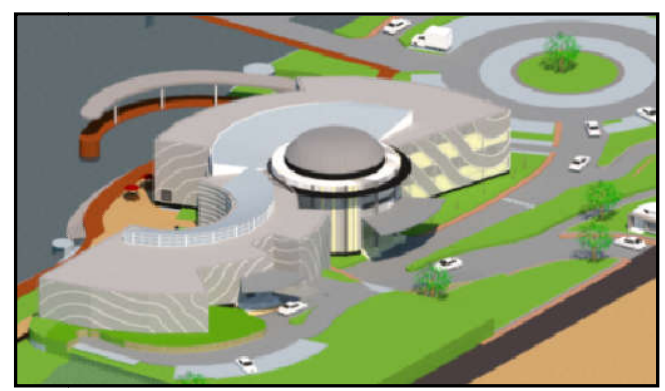

Figure 12. Building Perspective

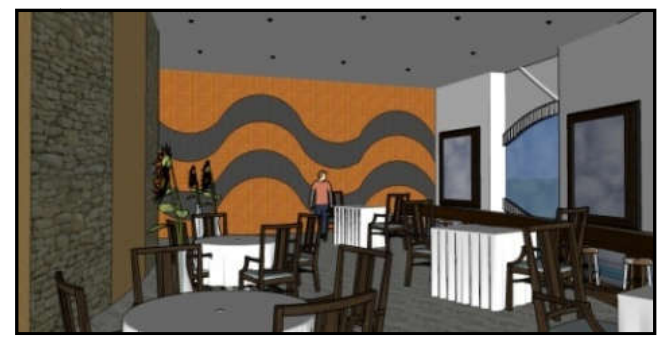

Figure 13. Restaurant at Second Floor

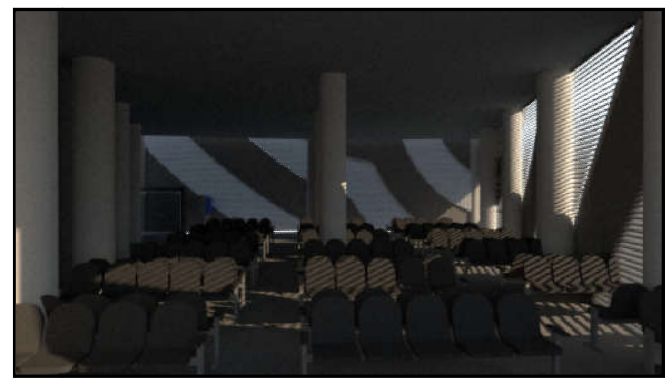

Figure 14. Waiting Room

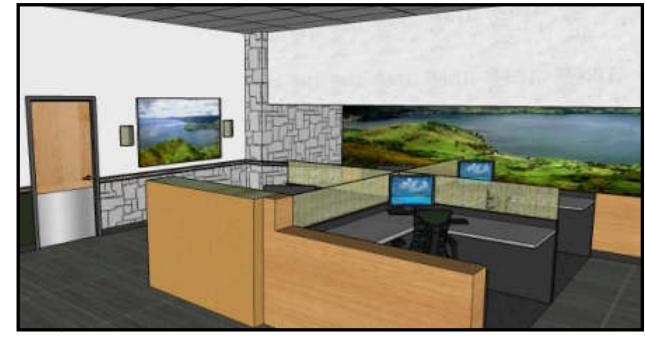

Figure 15. Restaurant $2^{\text {nd }}$ Floor

\section{Conclusion}

Project Tigaras dock area in Simalungun Regency with the concept of Organic Architecture design. With an area of $2 \mathrm{Ha}$ with Tread Area which is use $5886 \mathrm{~m}^{2}$. Building forms and landscape plans that use dynamic lines or do not seem rigid. For the laying and building, orientation obtains from the analysis of the tread that is a contour land but has a good view of Lake Toba. Building on the dock is function as a place that facilitates the needs of people in transportation such as crossing to the island of Samosir using an alternative route on the pier Tigaras. 


\section{Acknowledgment}

This research is part of the requirement to obtain a bachelor's degree in the Architecture Department of Universitas Sumatera Utara.

\section{REFERENCES}

[1] F. D.K.Ching. Arsitektur: Bentuk, Ruang dan Susunannya. Cetakan ke-7. Jakarta: Erlangga.1999.

[2] James C Synder. Pengantar Arsitektur, Jakarta: Erlangga. 1984.

[3] Frank Llyod Wright. The Natural House (H. Frick, Trans.). New York: Bramhall House Arsitektur dan Lingkungan. (Original work published 1954). 1988.

[4] Sugiyanto. Metodologi Penelitian. Surakarta : UNS Press. 2012. 